\title{
STATUS KEBERSIHAN MULUT ANAK USIA 9-11 TAHUN DAN KEBIASAAN MENYIKAT GIGI MALAM SEBELUM TIDUR DI SDN MELONGUANE
}

\author{
${ }^{1}$ Trisye Sampakang \\ ${ }^{2}$ Paulina N. Gunawan \\ ${ }^{3}$ Juliatri
}

\author{
${ }^{1}$ Kandidat Skripsi Program Studi Pendidikan Dokter Gigi \\ ${ }^{2}$ Program Studi Pendidikan Dokter Gigi \\ Fakultas Kedokteran Universitas Sam Ratulangi \\ Email:trisyesampakang@yahoo.co.id
}

\begin{abstract}
Abstrack: Children at primary school age need more attention because the risk of oral health problems. One way to maintain oral health is brushing your teeth before going to bed which plays an important role in preventing the development of bacteria that can cause tooth decay. Oral hygiene is measured by an examination of OHI-S by Green and Vermillion.This study was conducted to determine how the oral hygiene status of children aged 9-11 years by brushing at night before bed. This study is a descriptive study using purposive sampling method. The number of samples was 135 children aged 9-11 years consist of 53 children brushing their teeth at night before bed and 82 children who do not brush at night before bed. Results from this study showed 53 respondent brushing their teeth at night before bed and 82 respondent do not brush at night before bed. From children who brush their teeth at night before bed, 36 respondent had good OHI-S category and 1 has poor category. It showed that more than half of the children aged 9-11 years old who brush their teeth night before bed had a good OHI-S category which is 36 of 53 respondent.
\end{abstract}

Keywords: OHI-S, brushing teeth at night before bedtime, oral hygiene

\begin{abstract}
Abstrak: Anak usia sekolah dasar perlu mendapat perhatian lebih karena rentan terhadap gangguan kesehatan gigi dan mulut. Salah satu cara menjaga kesehatan gigi dan mulut yaitu menyikat gigi sebelum tidur yang berperan penting dalam pencegahan perkembangan bakteri yang dapat menyebabkan kerusakan gigi. Kebersihan gigi dan mulut diukur dengan pemeriksaan OHI-S menurut Green dan Vermillion. Penelitian ini dilakukan untuk mengetahui status kebersihan mulut anak usia 9-11 tahun menurut kebiasaan menyikat gigi malam sebelum tidur. Penelitian ini bersifat deskriptif dengan menggunakan metode pengambilan sampel purposif. Jumlah sampel 135 anak berusia 9-11 tahun yang terdiri dari 53 anak yang menyikat gigi malam sebelum tidur dan 82 anak yang tidak menyikat gigi malam sebelum tidur. Dari penelitian ini diperoleh $53(39,26 \%)$ responden yang menyikat gigi malam sebelum tidur dan $82(60,74 \%)$ responden yang tidak menyikat gigi malam sebelum tidur. Didapat 36 responden dengan kategori OHI-S baik dan 1 responden yang memiliki kategori OHI-S buruk pada responden yang menyikat gigi malam sebelum tidur. Dapat dilihat status kebersihan mulut anak usia 9-11 tahun menunjukkan lebih dari setengah responden yang menyikat gigi malam sebelum tidur memiliki kategori OHI-S baik yaitu 36 dari 53 responden.
\end{abstract}

Kata kunci: OHI-S, menyikat gigi malam sebelum tidur, kebersihan mulut

Kebersihan mulut penting untuk diperhatikan oleh masyarakat. Kurangnya menjaga kebersihan mulut dapat menyebabkan masalah seperti sakit pada gigi yang saat ini banyak dikeluhkan oleh masyarakat termasuk anak - anak. ${ }^{1}$ Menurut hasil Riset Kesehatan Dasar (RISKESDAS) 2013 prevalensi penduduk di Indonesia yang 
memiliki masalah gigi dan mulut sebesar $25,9 \% .^{2}$ Perilaku masyarakat terhadap kesehatan gigi, salah satunya diukur dengan kebiasaan menyikat gigi. ${ }^{3}$ Anak usia sekolah dasar perlu mendapat perhatian lebih karena rentan terhadap gangguan kesehatan gigi dan mulut.

Kesehatan gigi dan mulut anak pada umumnya ditandai dengan kondisi kebersihan mulut yang buruk dan sering dijumpai penumpukan plak dan deposit deposit lainnya pada permukaan gigi, sebab pengetahuan anak tentang waktu menyikat gigi yang tepat masih sangat kurang. ${ }^{4}$ Peran orang tua, guru dan tenaga kesehatan dalam mengajari anak merawat kebersihan mulut, melalui pemilihan dan penggunaan sikat gigi, cara dan waktu menyikat gigi yang benar dan tepat sejak dini sangat dibutuhkan.

Menyikat gigi sebelum tidur berperan penting dalam pencegahan perkembangan bakteri yang dapat menyebabkan kerusakan gigi. Menurut RISKESDAS 2013 tentang gigi dan mulut menunjukkan sebagian besar penduduk Indonesia yang menyikat gigi pada saat mandi pagi maupun mandi sore yaitu $(76,6 \%)$, sedangkan menyikat gigi dengan benar yaitu setelah makan pagi dan sebelum tidur malam ditemukan hanya $2,3 \%$. Prevalensi menyikat gigi malam sebelum tidur pada anak - anak di Indonesia sebesar 22,4\%, dan di Sulawesi Utara sebesar $32,4 \%$. $^{2}$ Penelitian yang dilakukan oleh Longginus E, dkk yang menunjukkan bahwa $48,21 \%$ anak menyikat gigi malam sebelum tidur. ${ }^{4} \mathrm{Hal}$ ini membuktikan bahwa masih banyak masyarakat yang belum menyadari akan pentingnya menyikat gigi malam sebelum tidur. Kebiasaan membersihkan gigi dan mulut dengan waktu yang tepat, terlebih pada malam sebelum tidur merupakan bentuk perilaku yang akan mempengaruhi baik atau buruknya kebersihan gigi dan mulut. ${ }^{5}$

Kurangnya tenaga kesehatan gigi di daerah tersebut merupakan salah satu hal yang dipertimbangan untuk memilih SDN
Melonguane sebangai tempat penelitian. Peran tenaga kesehatan sangat perlu untuk mengurangi masalah kesehatan gigi dan mulut terlebih khusus pada anak - anak usia sekolah dasar. Tempat yang berada di daerah pesisir yang jauh dari perkotaan sehingga kemungkinan pengetahuan tentang kebersihan gigi dan mulut masih kurang, keadaan ekonomi keluarga juga sebagian besar berada pada kondisi menengah kebawah, dan belum pernah dilakukan penelitian sebelumnya. Selain itu adanya dukungan dari pihak sekolah tersebut dalam kelangsungan penelitian ini.

Di Melonguane terdapat 1 puskesmas, dan salah satu program puskesmas yaitu penyuluhan, tetapi tidak diketahui sejauh mana keberhasilan dari program yang dilaksanakan tersebut. Oleh sebab itu penulis tertarik untuk meneliti tentang bagaimana status kebersihan mulut anak usia 9-11 tahun menurut kebiasaan menyikat gigi malam sebelum tidur di SDN Melonguane.

\section{METODE PENELITIAN}

Penelitian ini bersifat deskriptif dengan pendekatan cross sectional. Penelitian dilakukan di SDN Melonguane kabupaten Talaud pada bulan Agustus 2014. Populasi pada penelitian ini yaitu anak usia 9-11 tahun di SDN Melonguane pada bulan Agustus 2014 yaitu 162 anak. Pengambilan sampel pada penelitian ini menggunakan metode Purposive sampling yaitu pengambilan sampel berdasarkan pertimbangan tertentu yang dilakukan oleh peneliti. Dimana sampel diambil berdasarkan kriteria inklusi dan eksklusi. Sampel di ambil pada anak yang berusia 911 tahun di SDN Melonguane yaitu sebanyak 135 anak.

Kriteria inklusi yaitu anak umur 9-11 tahun, sehat jasmani dan rohani, bersifat koperatif, dan memiliki minimal 2 gigi indeks. Sedangkan kriteria ekslusi yaitu anak yang tidak kooperatif saat melakukan pemeriksaan, tidak hadir pada saat 
pemeriksaan dan tidak diberikan ijin oleh orang tua.

Penelitian diawali dengan mengajukan permohonan ijin ke pihak sekolah untuk melakukan penelitian di sekolah yang bersangkutan yakni SDN Melonguane. Lembar persetujuan menjadi subjek penelitian (informed consent) ditujukan kepada orang tua melalui anak yang bersangkutan dengan terlebih dahulu menjelaskan maksud dan tujuan penelitian yang akan dilaksanakan. Orang tua yang setuju anaknya menjadi subjek penelitian diminta untuk mengisi lembar persetujuan dan menandatanganinya.

Pengambilan data dilakukan berdasarkan kriteria inklusi dan eksklusi. Saat pemeriksaan peneliti dibantu oleh dua orang teman yang bertugas untuk mencatat hasil pemeriksaan yang dilakukan oleh peneliti dan merapikan alat yang digunakan saat penelitian berlangsung. Selanjutnya dilakukan dengan mengisi lembar pemeriksaan yang berisi data responden yaitu, nama, usia, jenis kelamin, dan menyikat gigi malam sebelum tidur atau tidak. Untuk mengukur kebersihan mulut dilakukan pemeriksaan OHI-S dengan menggunakan kaca mulut dan sonde. Pemeriksaan dilakukan dengan menggerakkan sonde secara mendatar pada permukaan gigi. Pemeriksaan dimulai dari sepertiga bagian insisal atau oklusal, jika pada bagian ini tidak ditemukan debris dan kalkulus lanjutkan terus pada dua pertiga bagian gigi, dan jika pada dua pertiga bagian gigi ini tidak ditemukan maka pemeriksaan dilanjutkan sampai pada sepertiga bagian servikal. Gigi-gigi yang dipilih sebagai gigi indeks beserta permukaan indeks yang dianggap mewakili tiap segmen yaitu Gigi 16 pada permukaan bukal, gigi 11 pada permukaan labial, gigi 26 pada permukaan bukal, gigi 36 pada permukaan lingual, gigi 31 pada permukan labial, gigi 46 pada permukaan lingual.

Kebersihan mulut diukur dengan menghitung indeks Oral Hygiene Index Simplified (OHI-S), yaitu :

Indeks $\mathrm{OHI}-\mathrm{S}=$ indeks debris + indeks kalkulus ${ }^{6}$

Dengan kriteria berikut :

Baik, bila nilainya antara $0,0-1,2$

Sedang, bila nilainya antara $1,3-3,0$

Buruk, bila nilainya antara $3,1-6,0$

Data yang diperoleh, dikumpulkan kemudian diolah dan dianalisis dengan cara persentase dan disajikan dalam bentuk tabel distribusi frekuensi.

HASIL PENELITIAN

Tabel 1. Distribusi karakteristik responden berdasarkan usia dan jenis kelamin

\begin{tabular}{ccccccc}
\hline Usia & \multicolumn{2}{c}{ laki - laki } & \multicolumn{2}{c}{ Perempuan } & \multicolumn{3}{c}{ Total } \\
\cline { 2 - 7 } & $\mathrm{n}$ & $\%$ & $\mathrm{n}$ & $\%$ & $\mathrm{n}$ & $\%$ \\
\hline 9 & 22 & 16,30 & 17 & 12,59 & 39 & 28,89 \\
10 & 30 & 22,22 & 28 & 20,74 & 58 & 42,96 \\
11 & 11 & 8,15 & 27 & 20,00 & 38 & 28,15 \\
\hline Total & 63 & 46,67 & 72 & 53,33 & 135 & 100,00 \\
\hline
\end{tabular}

Data pada tabel 1 menunjukkan responden usia 10 tahun memiliki jumlah tertinggi yaitu 58 responden $(42,96 \%)$, dan jumlah terendah yaitu ada pada usia 11 tahun yaitu
38 responden $(28,15 \%)$. Dan dilihat dari jenis kelamin responden dengan jenis kelamin perempuan memiliki jumlah lebih tinggi yaitu 72 responden $(53,33 \%)$. 
Tabel 2. Distribusi karakteristik responden berdasarkan menyikat gigi malam sebelum tidur atau tidak

\begin{tabular}{ccc}
\hline Menyikat gigi malam sebelum tidur & $\mathrm{n}$ & $\%$ \\
\hline Ya & 53 & 39,26 \\
Tidak & 82 & 60,74 \\
\hline Total & 135 & 100,00 \\
\hline
\end{tabular}

Data pada Tabel 2 menunjukkan bahwa dari 135 responden, terdapat 53 responden $(39,26 \%)$ yang menyikat gigi malam sebelum tidur, dan 82 responden $(60,74 \%)$ yang tidak menyikat gigi malam sebelum tidur.

Tabel 3. Distribusi kebersihan mulut berdasarkan usia

\begin{tabular}{|c|c|c|c|c|c|c|}
\hline \multirow{3}{*}{ OHI-S } & \multicolumn{6}{|c|}{ Usia } \\
\hline & \multicolumn{2}{|c|}{9} & \multicolumn{2}{|c|}{10} & \multicolumn{2}{|c|}{11} \\
\hline & $\mathrm{n}$ & $\%$ & $\mathrm{n}$ & $\%$ & $\mathrm{n}$ & $\%$ \\
\hline Baik & 21 & 53,85 & 39 & 67,25 & 16 & 42,10 \\
\hline Sedang & 17 & 43,59 & 17 & 29,31 & 20 & 52,64 \\
\hline Buruk & 1 & 2,56 & 2 & 3,44 & 2 & 5,26 \\
\hline Total & 39 & 100,00 & 58 & 100,00 & 38 & 100,00 \\
\hline
\end{tabular}

Data pada Tabel 3 menunjukkan bahwa kategori kebersihan mulut berdasarkan usia, terbanyak dengan kategori baik berada pada usia 10 tahun yaitu 39 responden $(67,25 \%)$ dan terendah ada pada usia 9 tahun dengan kategori buruk yaitu 1 responden $(2,56 \%)$.

Tabel 4. Distribusi kategori kebersihan mulut berdasarkan indeks OHI-S pada responden yang menyikat gigi malam sebelum tidur

\begin{tabular}{ccc}
\hline OHI-S & \multicolumn{2}{c}{ Menyikat gigi malam sebelum tidur } \\
\cline { 2 - 3 } & $\mathrm{n}$ & $\%$ \\
\hline Baik & 36 & 67,92 \\
Sedang & 16 & 30,19 \\
Buruk & 1 & 1,89 \\
\hline Total & 53 & 100,00 \\
\hline
\end{tabular}

Data pada Tabel 4 Menujukkan bahwa anak yang menyikat gigi malam sebelum tidur tertinggi dengan kategori OHI-S baik sebanyak 36 responden $(67,92 \%)$, dan terendah dengan kategori OHI-S buruk yaitu 1 responden $(1,89 \%)$.

Tabel 5. Distribusi kategori kebersihan mulut berdasarkan indeks OHI-S pada responden yang tidak menyikat gigi malam sebelum tidur

\begin{tabular}{ccc}
\hline OHI-S & \multicolumn{2}{c}{ Tidak menyikat gigi malam sebelum tidur } \\
\cline { 2 - 3 } & $\mathrm{n}$ & $\%$ \\
\hline Baik & 40 & 48,78 \\
Sedang & 38 & 46,36 \\
Buruk & 4 & 4,88 \\
\hline Total & 82 & 100,00 \\
\hline
\end{tabular}


Data pada Tabel 5 menunjukan bahwa anak yang tidak menyikat gigi malam sebelum tidur tertinggi dengan kategori OHI-S baik yaitu 40. responden $(48,78 \%)$ dan terendah dngan kategori OHI-S buruk yaitu 4 responden $(4,88 \%)$.

\section{BAHASAN}

Data pada tabel 1 menunjukkan bahwa dari 135 responden, jumlah responden perempuan lebih tinggi dari responden lakilaki yaitu 72 responden $(53,33 \%)$. Dilihat dari usia, responden usia 10 tahun lebih tinggi dari responden usia 9 dan 11 tahun yaitu 58 responden $(42,96 \%)$. Pada tabel 2 didapat 53 responden $(39,26 \%)$ menyikat gigi malam sebelum tidur dan 82 responden $(60,74 \%)$ tidak menyikat gigi malam sebelum tidur. Ini membuktikan bahwa kegiatan penyuluhan yang dilakukan oleh pihak Puskesmas setiap sebulan sekali belum berdampak baik. Saat ini penyuluhan yang diberikan hanya pada satu kelas berisi 20-30 anak setiap bulannya. Penyuluhan hanya diberikan oleh 2 perawat gigi dengan menggunakan alat bantu phantom dan sikat gigi. Dapat dilihat dari kebiasaan menyikat gigi responden yang sebagian besar belum menyikat gigi sesuai dengan waktu yang tepat.

Kebersihan gigi dan mulut seseorang diukur dengan memilih 6 permukaan gigi indeks yang mewakili segmen anterior maupun segmen posterior. ${ }^{6}$ Tingkat kebersihan gigi dan mulut ini berhubungan dengan kesadaran seseorang dalam menjaga kebersihan mulutnya dan waktu yang tepat menyikat gigi. ${ }^{22}$ Berdasarkan data pada tabel 3 dapat dilihat bahwa kategori kebersihan mulut brdasarkan usia didapat responden dengan usia 10 tahun dengan jumlah 39 responden $(67,25 \%)$ termasuk dalam status baik. dan paling sedikit terdapat pada usia 9 tahun dengan status kebersihan mulut buruk yaitu 1 responden $(2,56 \%)$. Dapat dilihat dari penelitian yang dilakukan oleh Adelia Barus yaitu tingkat pemahaman anak usia 10 tahun ke atas tentang penyuluhan kesehatan gigi dan mulut lebih baik. ${ }^{7}$

Hasil penelitian pada tabel 4 menunjukkan bahwa dari 53 responden yang menyikat gigi malam sebelum tidur terdapat 36 responden yang memiliki status kebersihan mulut baik. Ini menunjukan lebih dari setengah responden yang menyikat gigi malam sebelum tidur termasuk dalam status kebersihan mulut baik. Sama dengan hasil penelitian yang dilakukan oleh Rahayu tahun 2012 pada anak usia sekolah dasar di Madrasah Ibtidaiyah Al-Istiqomah Tangerang yaitu $56 \%$ anak SD sudah memiliki kebiasaan menyikat gigi malam sebelum tidur yang baik. Ini terjadi karena sebagian besar anak memiliki pengetahuan yang tinggi tentang waktu menyikat gigi yang benar, karena adanya pengawasan dan pengajaran dari orang tua dan guru. ${ }^{8}$

Data pada tabel 5 menunjukkan bahwa dari 82 responden yang tidak menyikat gigi malam sebelum tidur ada 40 responden yang memiliki status kebersihan mulut baik. Hal ini menunjukkan bahwa jumlah responden yang tidak menyikat gigi malam sebelum tidur tidak mencapai setengah dari jumlah responden. Ini di dukung dari penelitian yang dilakukan oleh Evenetus L pada siswa SD GMIM di Desa Wiau Lapi Barat dengan hasil hanya 27 dari 56 responden yang menyikat gigi malam sebelum tidur. Hal ini terjadi karena kesadaran responden tentang waktu menyikat gigi masih kurang, sehingga sangat diperlukan peran orang tua dalam mendidik anak untuk pemeliharaan kebersihan gigi sejak kecil. ${ }^{4}$

Perbedaan hasil penelitian ini juga dapat dipengaruhi oleh faktor ada atau tidaknya promosi kesehatan tentang waktu menyikat gigi malam sebelum tidur pada tempat penelitian. Promosi kesehatan yang lebih efektif dapat dilakukan dengan penyuluhan menggunakan slide dan memutar vidio bagaimana cara menyikat gigi dan waktu yang tepat menyikat gigi serta dilanjutkan dengan melaksanakan sikat gigi masal pada anak-anak, dapat juga dilakukan penyuluhan dengan metode 
ceramah dengan lembar balik, ini didukungdari penelitian yang dilakukan oleh Sri Hastuti tahun 2010 yang menyatakan pendidikan kesehatan dengan metode ceramah dengan lembar balik lebih efektif dibandingkan metode demontrasi dengan alat peraga gigi. ${ }^{9}$ Waktu menyikat gigi malam sebelum tidur sangat dianjurkan karena pada waktu tidur saliva berkurang, sehingga asam yang dihasilkan oleh plak menjadi lebih pekat dan kemampuannya merusak gigi menjadi lebih besar. ${ }^{6,8}$

\section{SIMPULAN}

$\begin{array}{lll}\text { Berdasarkan } & \text { penelitian } & \text { yang } \\ \text { dilaksanakan pada anak di SDN }\end{array}$ Melonguane dapat disimpulkan bahwa:

Status kebersihan mulut anak usia 9-11 tahun menunjukkan lebih dari setengah responden yang menyikat gigi malam sebelum tidur memiliki OHI-S dengan kategori baik yaitu 36 dari 53 anak.

\section{SARAN}

1. Bagi pihak sekolah disarankan kerja sama yang baik dengan pihak kesehatan khususnya puskesmas Melonguane dapat terus dipertahankan, dan diharapkan dapat mengadakan kegiatan penyuluhan dan sikat gigi masal secara teratur, serta melakukan pemeriksaan gigi setiap 6 bulan sekali.

2. Untuk penelitian lebih lanjut dapat melakukan pemeriksaan lebih mendalam lagi mengenai satus kebersihan mulut kepada lebih banyak anak, yang kemudian dikaitkan dengan status sosial, jenis kelamin dan cara menggosok gigi.

\section{DAFTAR PUSTAKA}

1. Nurhayati $O$, Tunggul PE, Wahyono $B$. Perbandingan media power point dengan flip chart dalam meningkatkan pengetahuan kesehatan gigi dan mulut. Unnes journal of public health [serial online]. 2012 [diakses februari 2014];1(1):31-35. Tersedia dalam: http://journal.unnes.ac.id/sju/index.php/uj $\mathrm{ph} /$ article/view/179/187

2. Laporan Riset kesehatan dasar Nasional 2013. Jakarta: Badan penlitian dan pengembangan kesehatan kementrian kesehatan RI [serial online]. 2013 [Diakses februari 2014];111,116-17. Tersedia dalam: www.litbang.depkes.go.id

3. Tjahja NI, Ghani L. Status kesehatan gigi dan mulut ditinjau dari faktor individu pengunjung puskesmas DKI Jakarta tahun 2007. Pusat penelitian dan pengembangan biomedis dan farmasi Jakarta [serial online]. 2010 [diakses februari 2014];38(2):52-66. Tersedia dalam: www.portalgaruda.org\%2Fdownload_arti cle.

4. Longginus E, Kaunang WPJ, Juliatri. Tindakan pemeliharaan kesehatan gigi dan mulut siswa SD GMIM di Desa Wiau Lapi Barat. Manado: Dentire journal; 2012 Juni;1(1): 27-34.

5. Anitasari S, Rahayu NE. Hubungan frekuensi menyikat gigi dengan tingkat kebersihan gigi dan mulut siswa sekolah dasar negeri di Kecamatan Palaran Kotamadya Samarinda Provinsi Kalimantan Timur. Majalah kedokteran gigi (Dent.J) 2005 April - Juni;38(2):88-90.

6. Putri MH, Herijulianti E, Nurjannah $\mathbf{N}$. Ilmu pencegahan penyakit jaringan keras dan jaringan pendukung gigi. Jakarta: EGC; 2011.p. 57, 85-6, 93-7,107-8.

7. Barus A. Kesehatan gigi dan mulut yang efektif dalam meningkatkan kecerdasan spiritual anak. [serial online] 2011 [diakses november 2014; 1-20. Tersedia dalam:

http://www.poltekkesjakarta1.ac.id/file/do kumen/95JURNAL_BARU pdf

8. Setiawati R. Hubungan kebiasaan menggosok gigi sebelum tidur malam dengan karies pada anak usia sekolah di Madrasah Ibtidaiyah Al-Istiqomah Tangerang. [Skripsi]. Depok: Universitas Indonesia; 2012.p. 31-31.

9. Hastuti S, Andriyani A. Perbedaan pengaruh pendidikan kesehatan gigi dalam meningkatkan pengetahuan tentang kesehatan gigi pada anak di SD Negeri 2 Sambi Kecamatan Sambi Kabupaten Boyolali. [serial online].2010 [diakses november 2014]; 624-632. Tersedia dalam: http://eprints.undip.ac.id/13646/1/2001MIK M1024.pdf 